\title{
Agronomic performance of beet cultivars as a function of phosphorus fertilization
}

\author{
Gerlani A. Silva ${ }^{1}$, Leilson C. Grangeiro ${ }^{1}$, Valdivia de F. L. Sousa ${ }^{1}$, Luiz R. R. Silva ${ }^{1}$, \\ Priscila M. M. Jesus ${ }^{1} \&$ Jorge L. A. Silva ${ }^{1}$ \\ 1 Universidade Federal Rural do Semi-Árido/Centro de Ciências Agrárias/Departamento de Ciências Agronômica e Florestal, Mossoró, RN, Brasil. \\ E-mail: gerlani_alves@hotmail.com - ORCID: 0000-0003-0894-4025; leilson@ufersa.edu.br (Corresponding author) - ORCID: 0000-0002-4613-3605; \\ valdivia_sousa@hotmail.com - ORCID: 0000-0002-5377-6844; luizricardo_5@hotmail.com - ORCID: 0000-0002-3346-478X; priscilamodesto@ymail.com - \\ ORCID: 0000-0002-3144-1832; jorgeluizalvesdasilva2014@gmail.com - ORCID: 0000-0001-8624-5639
}

\begin{abstract}
The lack of phosphorus in soil affects the development and productivity of plants; however, in order for them to express the full potential, it is necessary to supply this nutrient. The objective of this study was to define adequate doses of phosphorus, which maximize the productivity and quality of four beet cultivars, and to identify among them the most efficient use of phosphorus. The experiment was carried out at the Rafael Fernandes Experimental Farm, of the Federal Rural Semi-Arid University, Mossoró, RN state, Brazil, from July to October 2016. The experimental design was a randomized block in a $4 \mathrm{x} 4$ factorial scheme with four repetitions, corresponding to four beet cultivars (Early Wonder, Fortuna, Kestrel and Cabernet) and four doses of phosphorus $\left(0,90,180\right.$ and $270 \mathrm{~kg} \mathrm{ha}^{-1}$ of $\left.\mathrm{P}_{2} \mathrm{O}_{5}\right)$. The dose that maximized commercial productivity was $186 \mathrm{~kg} \mathrm{ha}^{-1}$ of $\mathrm{P}_{2} \mathrm{O}_{5}$ for the cultivars Early Wonder $\left(21.71 \mathrm{t} \mathrm{ha}^{-1}\right)$ and Kestrel $\left(22.59 \mathrm{t} \mathrm{ha}^{-1}\right)$, $180 \mathrm{~kg} \mathrm{ha}^{-1}$ of $\mathrm{P}_{2} \mathrm{O}_{5}$ for Carbenet $\left(25.82 \mathrm{t} \mathrm{ha}^{-1}\right)$ and $183 \mathrm{~kg} \mathrm{ha}^{-1}$ of $\mathrm{P}_{2} \mathrm{O}_{5}$ for Fortuna $\left(25.40 \mathrm{t} \mathrm{ha}^{-1}\right)$. The Cabernet and Fortuna cultivars were classified as not efficient but responsive, whereas Early Wonder and Kestrel were efficient but not responsive. Phosphorus did not influence content of soluble solids and percentage of white rings at the root.
\end{abstract}

Key words: Beta vulgaris L., productivity, mineral nutrition, soluble solids

\section{Desempenho agronômico de cultivares de beterraba em função da adubação com fósforo}

RESUMO: A carência do fósforo no solo afeta o desenvolvimento e a produtividade das plantas; no entanto, para que as mesmas expressem todo o potencial, faz-se necessário o fornecimento deste nutriente. Objetivouse no trabalho definir doses adequadas de fósforo, que maximizem a produtividade e qualidade de quatro cultivares de beterraba, e identificar entre elas, a mais eficiente quanto ao uso de fósforo. $\mathrm{O}$ experimento foi realizado na Fazenda Experimental Rafael Fernandes, da Universidade Federal Rural do Semi-Árido, Mossoró, RN, no período de julho a outubro de 2016. O delineamento utilizado foi em blocos casualizados, em esquema fatorial $4 \times 4$, com quatro repetições, correspondentes a quatro cultivares de beterraba (Early Wonder, Fortuna, Kestrel e Cabernet) e quatro doses de fósforo (0; 90; 180 e $270 \mathrm{~kg} \mathrm{ha}^{-1} \mathrm{de}_{2} \mathrm{P}_{5}$ ). A dose que

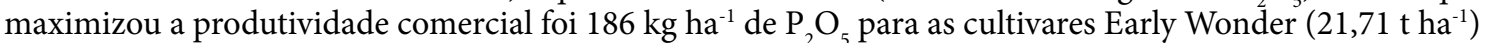
e Kestrel $\left(22,59 \mathrm{t} \mathrm{ha}^{-1}\right), 180 \mathrm{~kg} \mathrm{ha}^{-1}$ de $\mathrm{P}_{2} \mathrm{O}_{5}$ para Cabernet $\left(25,82 \mathrm{t} \mathrm{ha}^{-1}\right)$ e $183 \mathrm{~kg} \mathrm{ha}^{-1}$ de $\mathrm{P}_{2} \mathrm{O}_{5}$ para Fortuna $\left(25,40 \mathrm{t} \mathrm{ha}^{-1}\right)$. As cultivares Cabernet e Fortuna foram classificadas como não eficientes, mas responsivas, enquanto que, Early Wonder e Kestrel foram eficientes, mas não responsivas. O fósforo não influenciou no teor de sólidos solúveis e percentagem de anéis brancos na raiz.

Palavras-chave: Beta vulgaris L., produtividade, nutrição mineral, sólidos solúveis 


\section{INTRODUCTION}

In Brazil, beet crop is among the ten most produced vegetables, and the main producing regions are located in the states of São Paulo, Minas Gerais and Rio Grande do Sul. In the Northeast region, the cultivation of this vegetable is reduced because higher temperatures tend to decrease pigmentation and consequently the quality of the product (Marques et al., 2010).

From the nutritional and fertilization points of view, beet is considered as a soil-depleting crop because all the material harvested (roots and shoots) is removed from the field (Sediyama et al., 2011). In a literature review on the beet crop, Trani et al. (2013) found that, for root production between 20 and $65 \mathrm{tha}^{-1}$, the quantities of macronutrients extracted were 78 to $275 \mathrm{~kg} \mathrm{ha}^{-1}$ of $\mathrm{N}$; 18 to $40 \mathrm{~kg} \mathrm{ha}^{-1}$ of P (41 to $92 \mathrm{~kg} \mathrm{ha}^{-1}$ of $\mathrm{P}_{2} \mathrm{O}_{5}$ ); 83 to $476 \mathrm{~kg} \mathrm{ha}^{-1}$ of $\mathrm{K}_{2} \mathrm{O}$ (100 to $571 \mathrm{~kg} \mathrm{ha}^{-1}$ of $\mathrm{K}_{2} \mathrm{O}$ ); 20 to $74 \mathrm{~kg} \mathrm{ha}^{-1}$ of $\mathrm{Ca}$ and 27 to $62 \mathrm{~kg} \mathrm{ha}^{-1}$ of $\mathrm{Mg}$.

Despite the lower extraction of $\mathrm{P}$ by beet plants, compared to the other macronutrients, $\mathrm{P}$ is the nutrient applied in largest amount. This fact is due to the low availability of $\mathrm{P}$ in tropical soils associated with its low mobility in soil and high affinity to iron and aluminum oxides (Novais et al., 2007), as well as the low efficiency of $\mathrm{P}$ acquisition and use by plants (Wang et al., 2010), which increases the need for its incorporation in fertilization programs. As for beet capacity of response to phosphate fertilization, studies are limited. However, Avalhães et al. (2009) and Fernandes et al. (2015) observed significant increments in the marketable yield of roots with addition of $P$.

This study aimed to define adequate doses of $\mathrm{P}$, which maximize the yield and quality of four beet cultivars, and identify the most efficient of these cultivars with respect to P use.

\section{Material ANd Methods}

The experiment was conducted in the period from July to October 2016, at the Fazenda Experimental Rafael Fernandes of the Universidade Federal Rural do Semiárido, located in the district of Lagoinha, in the rural area of the municipality of Mossoró, RN state, Brazil ( $5^{\circ} 3^{\prime} 37^{\prime \prime} \mathrm{S}, 37^{\circ} 23^{\prime} 50^{\prime \prime} \mathrm{W}$ and approximate altitude of $72 \mathrm{~m}$ ). During the experimental period, the weather of the region was monitored and the average temperature was $28.7{ }^{\circ} \mathrm{C}$, with average relative humidity of $65.3 \%$.

The soil of the experimental area was classified as Ultisol. Chemical analysis in soil samples from the $0-20 \mathrm{~cm}$ layer revealed following mean values of the variables: $\mathrm{pH}\left(\mathrm{H}_{2} \mathrm{O}\right)=5.6$; $\mathrm{EC}=0.05 \mathrm{dS} \mathrm{m}{ }^{-1} ; \mathrm{P}=2.0 \mathrm{mg} \mathrm{dm}^{-3} ; \mathrm{K}^{+}=55.6 \mathrm{mg} \mathrm{dm}^{-3}$; $\mathrm{Na}^{+}=3.3 \mathrm{mg} \mathrm{dm}{ }^{-3} ; \mathrm{Ca}^{2+}=1.04 \mathrm{cmol}_{\mathrm{c}} \mathrm{dm}^{-3} ; \mathrm{Mg}^{2+}=0.581 \mathrm{~mol}_{\mathrm{c}} \mathrm{dm}^{-3}$.

The experimental design was randomized blocks with $4 \times 4$ factorial scheme, with four repetitions, corresponding to four doses of phosphorus (0; 90; 180 and $270 \mathrm{~kg} \mathrm{ha}^{-1}$ of $\mathrm{P}_{2} \mathrm{O}_{5}$ ) and four beet cultivars (Early Wonder, Fortuna, Kestrel and Cabernet). The experimental unit was represented by a $3.00 \times 1.20 \mathrm{~m}$ bed, containing four rows of plants spaced by $0.30 \times 0.10 \mathrm{~m}$, and the two central rows were used for evaluations, disregarding one plant at each end.
Soil tillage consisted of plowing and harrowing, followed by the raising of the beds. Fertilization was performed based on soil chemical analysis and on the recommendation for the crop, according to Cavalcanti et al. (2008), using $75 \mathrm{~kg} \mathrm{ha}^{-1}$ of $\mathrm{K}_{2} \mathrm{O}, 54 \mathrm{~kg} \mathrm{ha}^{-1}$ of $\mathrm{N}, 4.0 \mathrm{~kg} \mathrm{ha}^{-1}$ of $\mathrm{B}$ and $9.0 \mathrm{~kg} \mathrm{ha}^{-1}$ of $\mathrm{Zn}$, respectively in the forms of potassium chloride, urea, boric acid and zinc sulfate. Phosphorus was applied entirely at planting, at doses according to the treatments, in the form of triple superphosphate.

Topdressing fertilizations were carried out in two applications, at 25 and 45 days after planting (DAP), with $52.5 \mathrm{~kg} \mathrm{ha}^{-1}$ of $\mathrm{N}$, in the form of ammonium sulfate and $57.5 \mathrm{~kg} \mathrm{ha}^{-1}$ of $\mathrm{K}_{2} \mathrm{O}$ in the form of potassium chloride. At 50 days after sowing (DAS), $0.7 \mathrm{~kg} \mathrm{ha}^{-1}$ of Rexolin was applied as source of micronutrients $\left(11.6 \%\right.$ of $\mathrm{K}_{2} \mathrm{O}, 1.28 \%$ of $\mathrm{S}, 0.86 \%$ of $\mathrm{Mg}, 2.1 \%$ of $\mathrm{B}, 0.36 \%$ of $\mathrm{Cu}, 2.66 \%$ of $\mathrm{Fe}, 2.48 \%$ of $\mathrm{Mn}, 0.036 \%$ of Mo and 3.38\% of $\mathrm{Zn}$ ).

Sowing was carried out manually, by placing three to four seed clusters per hole at approximately $2.0 \mathrm{~cm}$ depth, and thinning was performed 18 DAS, leaving only one plant per hole at $0.30 \times 0.10 \mathrm{~m}$ spacing.

Irrigations were applied by a micro-sprinkler system, with daily applications (morning and afternoon), and the depths were determined according to the requirement of the crop, providing approximately $597 \mathrm{~mm} \mathrm{ha}^{-1}$. Cultivation practices were manual weeding three times and covering the tubers with soil, once at 40 DAS. Harvest was carried out at 80 DAS and the evaluated characteristics were:

-Leaf and root dry masses ( g plant $\left.^{-1}\right)$ : at harvest five plants were collected in the evaluation area, separated into leaves and roots, placed in paper bags and dried in a forced air circulation oven set at temperature of $65^{\circ} \mathrm{C}$ until constant weight.

-Classification of roots (\%): performed based on the transverse diameter of the roots (RD), adapted according to the methodology of Horta et al. (2001), as: extra (RD from 4.0 to less than $5.0 \mathrm{~cm}$ ); extra A (RD from 5.0 to less than 6.0 $\mathrm{cm}$ ); extra AA (RD from 6.0 to less than $7.0 \mathrm{~cm}$ ) and large (RD from 7.0 to less than $8.0 \mathrm{~cm}$ ) and extremely large (RD greater than $8.0 \mathrm{~cm}$ ), considering as waste all roots that were injured, cracked, bifurcated and with diameter smaller than $4.0 \mathrm{~cm}$.

-Marketable yield of roots $\left(\mathrm{t} \mathrm{ha}^{-1}\right)$ : determined by summing the production of roots with diameter $>4.0 \mathrm{~cm}$, with no cracks, bifurcations or mechanical injuries.

-Unmarketable yield of roots $\left(\mathrm{t} \mathrm{ha}^{-1}\right)$ : determined by summing the production of roots with diameter $<4.0 \mathrm{~cm}$ and/or showing cracks, bifurcations and mechanical injuries.

-Total yield of roots $\left(\mathrm{t} \mathrm{ha}^{-1}\right)$ : determined by summing the marketable and unmarketable yields.

-Classification of the cultivars for their efficiency and response to phosphate fertilization (Fageria \& Kluthcouski, 1980). The response index (RI) was obtained by the difference between the yields with $\mathrm{P}_{2} \mathrm{O}_{5}$ application of $180 \mathrm{~kg} \mathrm{ha}^{-1}$ and without $\mathrm{P}$, divided by the difference between $\mathrm{P}$ doses.

The classification of cultivars was performed by graphic representation on Cartesian plan. The $\mathrm{X}$-axis shows the yield of roots obtained without $\mathrm{P}$ application, whereas the $\mathrm{Y}$-axis shows the response index. The point of origin of the axes is 
the average yield of the cultivars without $\mathrm{P}$ application and the average response index. Efficient and responsive cultivars are represented in the first quadrant; non-efficient and responsive cultivars are shown in the second quadrant; non-efficient and non-responsive cultivars are shown in the third quadrant; and efficient and non-responsive cultivars are represented in the fourth quadrant.

-Percentage of white rings in the roots - RINGS (\%): determined in 10 roots selected from the evaluation area to check for the absence or presence of white rings.

-Total soluble solids - TSS ( ${ }^{\circ}$ Brix): juice was extracted from 10 tuberous roots plot $^{-1}$, which were chopped in domestic multi-processor and filtered in a funnel through filter paper. Reading was taken in a digital refractometer (Hanna, HI96800 model).

The data were subjected to analysis of variance and, when there was significant effect, means were compared by Tukey test at 0.05 probability level for the qualitative factor (cultivars) and regression analysis was conducted for the quantitative factor (doses), using the program Sisvar version 5.6 (Ferreira, 2011).

\section{Results AND Discussion}

The interaction between cultivar and $\mathrm{P}$ doses was significant for leaf dry mass (LDM), root dry mass (RDM), total yield (TY) and marketable yield (MY). For unmarketable yield, none of the studied factors caused significant effect. In the classification of tuberous roots, only $\mathrm{P}$ doses caused a significant effect, except for the class large (LG), which also differed between cultivars. For soluble solids and percentage of white rings in the root, there were differences among the cultivars (Table 1).

Leaf dry mass (LDM) increased with P application, showing maximum values of $6.0 \mathrm{~g} \mathrm{plant}^{-1}$ for the cultivar Early Wonder at $\mathrm{P}_{2} \mathrm{O}_{5}$ dose of $152 \mathrm{~kg} \mathrm{ha}^{-1}$, and 5.04 and $5.11 \mathrm{~g} \mathrm{plant}^{-1}$, respectively, for Cabernet and Kestrel, at $\mathrm{P}_{2} \mathrm{O}_{5}$ dose of $270 \mathrm{~kg} \mathrm{ha}^{-1}$. For Fortuna, no regression model was fitted and the average LDM was 3.23 g plant $^{-1}$ (Figure 1A).

The LDM of the cultivars Carbenet and Kestrel increased by 78 and $68 \%$ respectively, comparing the dose which led to maximum LDM $\left(270 \mathrm{~kg} \mathrm{ha}^{-1}\right.$ of $\left.\mathrm{P}_{2} \mathrm{O}_{5}\right)$ and the treatment without $\mathrm{P}$ application. For Early Wonder, such increment was $20 \%$ with addition of $152 \mathrm{~kg} \mathrm{ha}^{-1}$ of $\mathrm{P}_{2} \mathrm{O}_{5}$, compared to the absence of phosphate fertilization (Figure 1A).
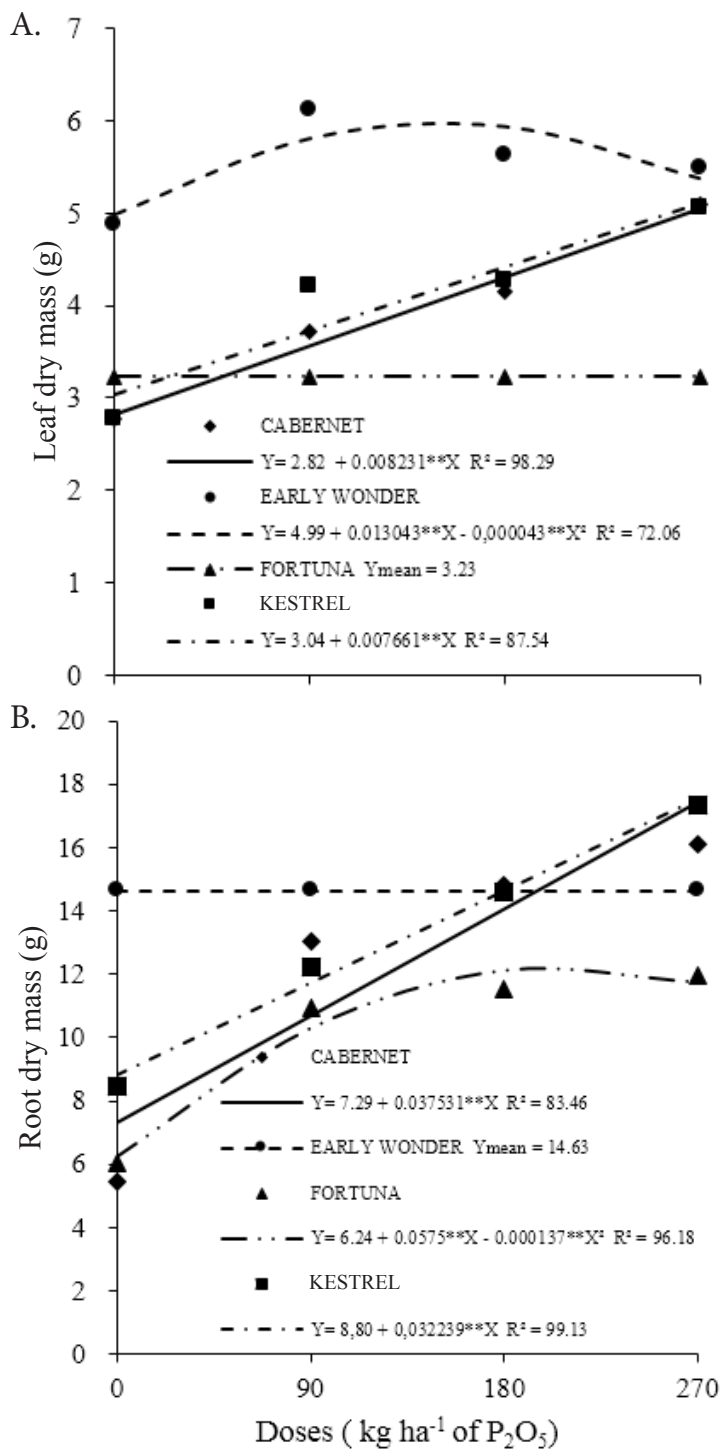

Figure 1. Leaf dry mass (A) and root dry mass (B) of the beet cultivars Cabernet, Early Wonder, Fortuna and Kestrel as a function of phosphorus doses

In the treatment without $\mathrm{P}$ application, plants of all cultivars showed visual symptoms of deficiency. Initially, leaves exhibited a purplish red color and plants showed a reduced growth. There was also a reduction in root size and number of leaves per plant, compared to the other treatments. Alves et al. (2008), in a study with omission of $\mathrm{P}$ in the nutrient

Table 1. Summary of analysis of variance for the characteristics leaf dry mass (LDM), root dry mass (RDM), total yield (TY), marketable yield (MY), unmarketable yield (UY), roots classified as extremely large (XLG), large (LG), extra AA (EXAA), extra A (EXA), extra (EX) and waste (WST), white rings inside the root (RINGS) and total soluble solids (TSS)

\begin{tabular}{|c|c|c|c|c|c|c|c|c|}
\hline \multirow{2}{*}{ S.V. } & \multirow{2}{*}{ D.F. } & \multicolumn{7}{|c|}{ Mean square } \\
\hline & & LDM & RDM & TY & MY & UY & XLG & $\mathbf{L G}$ \\
\hline Blocks & 3 & $0.20^{\text {ns }}$ & $1.11^{\mathrm{ns}}$ & $15.48^{\text {ns }}$ & $14.73^{\text {ns }}$ & $0.16^{\mathrm{ns}}$ & $534.81^{\text {ns }}$ & $425.800^{\text {ns }}$ \\
\hline Cultivar (C) & 3 & $14.95^{\star \star}$ & $56.84^{* *}$ & $2.56^{\text {ns }}$ & $4.11^{\mathrm{ns}}$ & $0.57^{\mathrm{ns}}$ & $128.37^{\text {ns }}$ & $273.26^{\star *}$ \\
\hline Dose (D) & 3 & $5.01^{* \star}$ & $138.06^{\star \star}$ & $506.17^{\star \star}$ & $487.38^{\star \star}$ & $0.20^{\text {ns }}$ & $1902.77^{\star \star}$ & $1703.08^{\star \star}$ \\
\hline$C \times D$ & 9 & $1.20^{* *}$ & $18.66^{* *}$ & $18.30^{\star *}$ & $18.48^{* *}$ & $0.26^{n s}$ & $110.95^{\text {ns }}$ & $56.53^{\text {ns }}$ \\
\hline C.V (\%) & & 14.47 & 8.29 & 12.89 & 12.80 & 160.01 & 54.21 & 24.91 \\
\hline & & EXAA & EXA & EX & WST & RINGS & TSS & \\
\hline Blocks & 3 & $7.74^{\mathrm{ns}}$ & $33.96^{\text {ns }}$ & $656.65^{\text {ns }}$ & $2.91^{\mathrm{ns}}$ & $278.52^{\text {ns }}$ & $9.75^{\text {ns }}$ & \\
\hline Cultivar (C) & 3 & $228.66^{\mathrm{ns}}$ & $57.26^{\text {ns }}$ & $175.07^{\mathrm{ns}}$ & $6.63^{\text {ns }}$ & $5570.18^{* *}$ & $37.09^{* *}$ & \\
\hline Dose (D) & 3 & $105.100^{\text {ns }}$ & $1193.84^{* *}$ & $3641.96^{* *}$ & $2.65^{\mathrm{ns}}$ & $163.93^{\text {ns }}$ & $1.50^{\text {ns }}$ & \\
\hline$C \times D$ & 9 & $52.77^{\mathrm{ns}}$ & $36.15^{\text {ns }}$ & $63.64^{\mathrm{ns}}$ & $2.56^{\mathrm{ns}}$ & $502.82^{\mathrm{ns}}$ & $0.68^{\text {ns }}$ & \\
\hline C.V (\%) & & 50.22 & 56.66 & 116.09 & 180.36 & 28.06 & 11.95 & \\
\hline
\end{tabular}

${ }^{* *}$ Significant at 0.01 probability $(\mathrm{p}<0.01) ;{ }^{*}$ Significant at 0.05 probability $(\mathrm{p}<0.05) .{ }^{\text {ns }}$ Not significant; C.V - Coefficient of variation; S.V. - Source of variation; D.F. - Degrees of freedom 
solution, observed similar symptoms to those found here, such as intense purplish color in beet leaves and stoppage of tuberous root growth.

The highest values of root dry mass (RDM) were obtained at $\mathrm{P}_{2} \mathrm{O}_{5}$ doses of $210 \mathrm{~kg} \mathrm{ha}^{-1}$ for Fortuna $\left(12.27 \mathrm{~g} \mathrm{plant}^{-1}\right)$ and of $270 \mathrm{~kg} \mathrm{ha}^{-1}$ for Carbenet (17.42 $\mathrm{g} \mathrm{plant}^{-1}$ ) and Kestrel (17.51 $\mathrm{g} \mathrm{plant}^{-1}$ ). For Early Wonder no model was fitted (Figure 1B). Tuberous root dry mass production was influenced by $\mathrm{P}$ doses in the study conducted by Oliveira et al. (2016) with the beet cultivar Early Wonder. Maximum production was obtained with the application of $385 \mathrm{~kg} \mathrm{ha}^{-1}$ of $\mathrm{P}_{2} \mathrm{O}_{5}$, which led to a $52 \%$ increase compared to the absence of phosphate fertilization.

In other vegetables, the responses were also positive for dry mass production due to phosphate fertilization, such as in carrot (Assunção et al., 2016), radish (Nunes et al., 2014) and potato (Luz et al., 2013; Fernandes et al., 2015).

The means of total yield of tuberous roots (TY) were significantly fitted to quadratic regression models for all beet cultivars. The doses which maximized TY in the cultivars Cabernet (26.32 $\left.\mathrm{t} \mathrm{ha}^{-1}\right)$, Early Wonder $\left(22.25 \mathrm{t} \mathrm{ha}^{-1}\right)$, Fortuna $\left(25.35 \mathrm{t} \mathrm{ha}^{-1}\right)$ and Kestrel $\left(23.11 \mathrm{t} \mathrm{ha}^{-1}\right)$ were respectively 178 , 196, 182 and $184 \mathrm{~kg} \mathrm{ha}^{-1}$ of $\mathrm{P}_{2} \mathrm{O}_{5}$ (Figure 2A). From these doses, there was a reduction of TY in all cultivars. Compared to the treatment without $\mathrm{P}$ application, the increments were respectively 219, 66, 149 and 57\%, for Cabernet, Early Wonder, Fortuna and Kestrel.

The evaluated cultivars responded to the doses of phosphate fertilizers close to those recommended for the beet crop in Pernambuco state (used as reference in this study), except for Fortuna, which was higher $\left(196 \mathrm{~kg} \mathrm{ha}^{-1}\right.$ of $\left.\mathrm{P}_{2} \mathrm{O}_{5}\right)$. For soils with $\mathrm{P}$ content $<11 \mathrm{mg} \mathrm{dm}^{-3}$, the recommendation is $180 \mathrm{~kg} \mathrm{ha}^{-1}$ of $\mathrm{P}_{2} \mathrm{O}_{5}$ for a population of 333,333 plants $\mathrm{ha}^{-1}$ and expected yield of $30 \mathrm{t} \mathrm{ha}^{-1}$ (Cavalcanti et al., 2008).

Beet response to $\mathrm{P}$ application can be explained by the low $\mathrm{P}$ availability in the soil $\left(2.0 \mathrm{mg} \mathrm{dm}^{-3}\right)$ used in this study, because the effects of phosphate fertilizations on crops are more accentuated in low-fertility soils (Novais et al., 2007). In soil with low $\mathrm{P}$ availability $\left(\mathrm{P}=2.5 \mathrm{mg} \mathrm{dm}^{-3}\right)$, Oliveira et al. (2016) also obtained increments in beet root production as a function of $\mathrm{P}$ application, with maximum values in two experiments at $\mathrm{P}_{2} \mathrm{O}_{5}$ doses of 379 and $400 \mathrm{~kg} \mathrm{ha}^{-1}$.

In potato, a study conducted in soils with different initial values of $\mathrm{P}$ availability also demonstrated that, in soil with low $\mathrm{P}$ availability $\left(\mathrm{P}_{\text {resin }}=14 \mathrm{mg} \mathrm{dm}^{-3}\right)$, the relative yield of tubers with the use of approximately $500 \mathrm{~kg} \mathrm{ha}^{-1}$ of $\mathrm{P}_{2} \mathrm{O}_{5}$ was about $76 \%$ higher than in the treatment without $\mathrm{P}$ application. However, in soils with intermediate $\left(\mathrm{P}_{\text {resin }}=36 \mathrm{mg} \mathrm{dm}^{-3}\right)$ and high $\left(\mathrm{P}_{\text {resin }}=70 \mathrm{mg} \mathrm{dm}^{-3}\right)$ $P$ availability, tuber yields with phosphate fertilization were 30 and $18 \%$ higher than that in the control, respectively, but increased only at $\mathrm{P}_{2} \mathrm{O}_{5}$ doses of 250 and $125 \mathrm{~kg} \mathrm{ha}^{-1}$.

Thus, in soils with higher $\mathrm{P}$ availability, the beet crop response to phosphate fertilization is small and of lower magnitude, because it is directly related to the initial availability of P (Fernandes \& Soratto, 2016).

Quadratic regression models were fitted to the means of marketable yield of tuberous roots (MY, Figure 2B) for all cultivars, as observed for TY. The doses which maximized MY in the cultivars Cabernet $\left(25.82 \mathrm{t} \mathrm{ha}^{-1}\right)$, Early Wonder
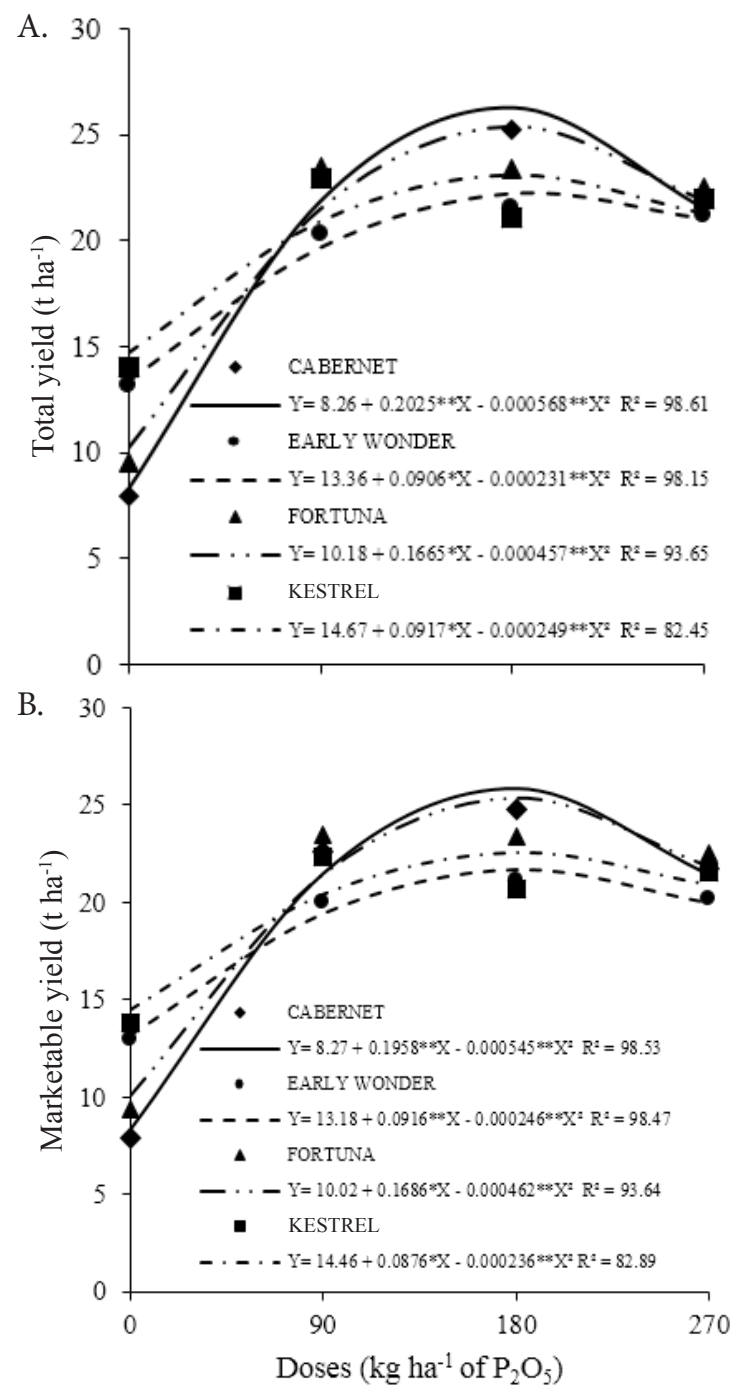

Figure 2. Total yield (A) and marketable yield (B) of roots of the beet cultivars Cabernet, Early Wonder, Fortuna and Kestrel as a function of phosphorus doses

(21.71 tha $\left.{ }^{-1}\right)$, Fortuna $\left(25.40\right.$ tha $\left.^{-1}\right)$ and Kestrel $\left(22.59\right.$ tha $\left.^{-1}\right)$ were respectively 180,186, 183 and $186 \mathrm{~kg} \mathrm{ha}^{-1}$ of $\mathrm{P}_{2} \mathrm{O}_{5}$ (Figure 2B). In relation to the treatment without $\mathrm{P}$ application, the increments were respectively 213, 65, 153 and 56\%, for Cabernet, Early Wonder, Fortuna and Kestrel. The MY remained around the national average, which varies between 20 and $35 \mathrm{t} \mathrm{ha}^{-1}$, according to Sediyama et al. (2011).

The use of the highest $\mathrm{P}$ dose $\left(270 \mathrm{~kg} \mathrm{ha}^{-1}\right.$ of $\left.\mathrm{P}_{2} \mathrm{O}_{5}\right)$ led to reductions of $17,8,14$ and $7 \%$, respectively, in the marketable yield of the beet cultivars Cabernet, Early Wonder, Fortuna and Kestrel, compared to the doses which maximized the MY (Figure 2B).

In the classification of the cultivars with respect to efficiency and response to phosphate fertilization, according to the methodology proposed by Fageria \& Kluthcouski (1980), Cabernet and Fortuna were classified as non-efficient, but responsive, indicating that they produce little under conditions of low P levels in soil, but respond well to fertilization with this nutrient (Figure 3). Phosphate fertilization in these cultivars caused a significant increase in the yield of tuberous roots. Cabernet stood out with the lowest TY in the environment with low P content (treatment without application) and also 


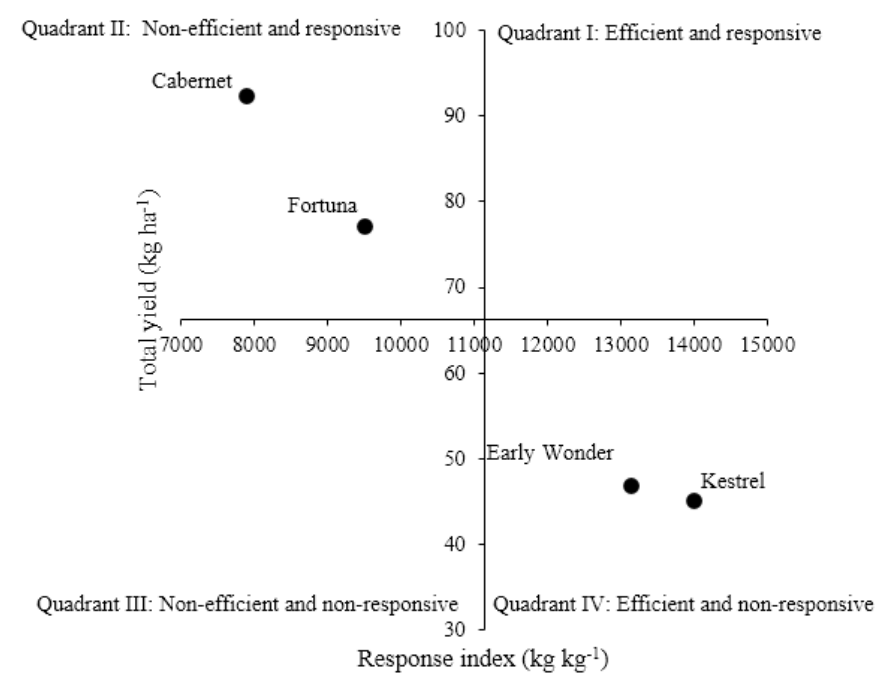

Figure 3. Use efficiency and response to phosphorus application with respect to the yield of beet cultivars, according to the methodology of Fageria \& Kluthcouski (1980)

the lowest TY of the present study in the same environment; however, the TY increased by $219 \%$ compared to the environment with application of $180 \mathrm{~kg} \mathrm{ha}^{-1}$ of $\mathrm{P}_{2} \mathrm{O}_{5}$. In the case of Fortuna, the increment was 149\%.

The highest estimated percentages of roots classified as large (41.7\%) and extremely large (33.7\%) were respectively obtained at the $\mathrm{P}_{2} \mathrm{O}_{5}$ doses of 270 and $178 \mathrm{~kg} \mathrm{ha}^{-1}$ (Figures $4 \mathrm{~A}$ and $\mathrm{B}$ ).
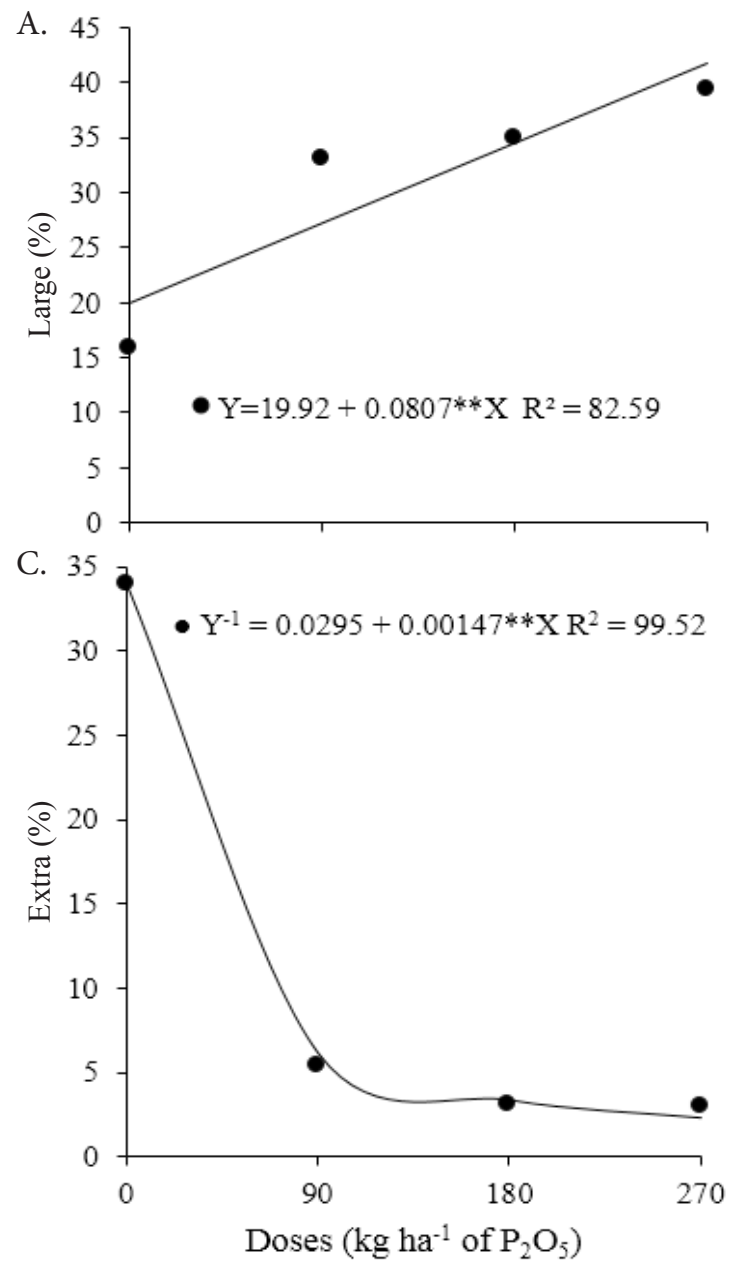

Figure 4. Percentage of beet roots classified as large (A), extremely large (B), extra (C) and extra A (D), as a function of phosphorus doses
Phosphorus caused increase in the production of roots with diameter greater than $7 \mathrm{~cm}$, considered in the market as those with best prices (Horta et al., 2001). Avalhães et al. (2009) and Oliveira et al. (2016) also obtained increase in beet root diameter with $\mathrm{P}$ application. Early Wonder was inferior to the other cultivars, despite not differing significantly from Cabernet (Table 2).

The percentages of beet roots classified as Extra and Extra A decreased as $\mathrm{P}$ doses increased. In the absence of $\mathrm{P}$ application, the percentages were 33.89 and $26 \%$ for Extra and Extra A, respectively (Figures 4C and D). The Early Wonder cultivar produced a smaller percentage of large roots (LG), not statistically different from Carbenet. The highest values were for cultivars Kestrel and Fortuna, with percentages of 34.41 and $34.18 \%$, respectively (Table 2 ).

The cultivar Cabernet had lower percentage of white rings in the tuberous root, whereas the others did not differ from

Table 2. Mean values for percentages of large roots (LG), presence of rings (RINGS) and total soluble solids (TSS) in beet cultivars

\begin{tabular}{|c|c|c|c|}
\hline \multirow{2}{*}{ Cultivar } & LG & RINGS & \multirow{2}{*}{$\begin{array}{l}\text { TSS } \\
\text { ('Brix) }\end{array}$} \\
\hline & \multicolumn{2}{|c|}{$(\%)$} & \\
\hline Cabernet & $28.55 a b$ & $32.81 \mathrm{~b}$ & $12.28 \mathrm{a}$ \\
\hline Early Wonder & 26.14 b & $73.75 \mathrm{a}$ & $10.84 \mathrm{~b}$ \\
\hline Fortuna & $34.18 \mathrm{a}$ & $70.63 \mathrm{a}$ & $9.20 \mathrm{C}$ \\
\hline Kestrel & $34.41 \mathrm{a}$ & $61.88 \mathrm{a}$ & $12.48 \mathrm{a}$ \\
\hline
\end{tabular}

Means followed by the same lowercase letter in the column do not differ statistically by Tukey test at $\mathrm{p} \leq 0.05$
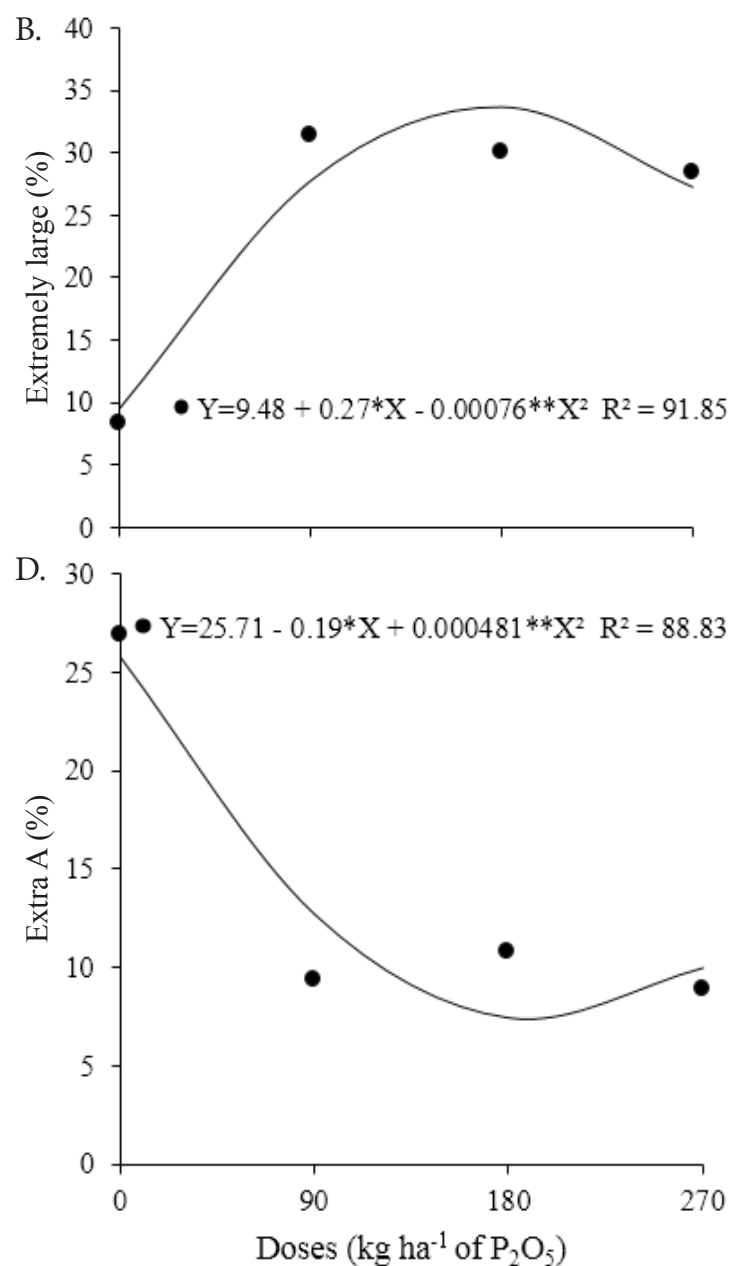
one another (Table 2). It is a physiological disorder caused by high temperatures $\left(25\right.$ to $\left.30^{\circ} \mathrm{C}\right)$, which besides reducing the concentrations of pigments in the roots, especially betacyanin (red color), depreciates the quality of the product in the market (Puiatti \& Finger, 2005). The period of highest incidence of this disorder is the summer, when it may affect 20 to $25 \%$ of the area.

The cultivars Cabernet and Kestrel had higher contents of total soluble solids than the others (Table 2). Sanches et al. (2008) observed no change of TSS in different beet crops, which showed a range between 8.18 and $10.03^{\circ}$ Brix, as Coutinho (2016) found that a range from 7.80 to $9.05^{\circ} \mathrm{Brix}$, both lower than in the present study. Harrill (1998) stated that ${ }^{\circ}$ Brix, as a measure of soluble solids content, varies directly with plant quality. For table beet, Harrill (1998) suggested a quality scale that assigned a Brix of $6,8,10$, and 14 to poor, average, good, and excellent quality labels, respectively.

\section{Conclusions}

1. The $\mathrm{P}_{2} \mathrm{O}_{5}$ doses which maximized the marketable yield were $186 \mathrm{~kg} \mathrm{ha}^{-1}$ for the cultivars Early Wonder $\left(21.71 \mathrm{t} \mathrm{ha}^{-1}\right)$ and Kestrel (22.59 $\left.\mathrm{t} \mathrm{ha}^{-1}\right), 180 \mathrm{~kg} \mathrm{ha}^{-1}$ for Cabernet $\left(25.82 \mathrm{t} \mathrm{ha}^{-1}\right)$ and $183 \mathrm{~kg} \mathrm{ha}^{-1}$ for Fortuna (25.40 $\left.\mathrm{t} \mathrm{ha}^{-1}\right)$.

2. The cultivars Cabernet and Fortuna were classified as non-efficient, but responsive, to phosphate fertilization, whereas Early Wonder and Kestrel were classified as efficient but non-responsive.

3. Phosphorus did not influence the content of soluble solids and percentage of white rings in the tuberous roots of beet plants.

\section{Literature Cited}

Alves, A. U.; Prado, R. de M.; Gondim, A. R. de O.; Fonseca, I. M.; Cecílio Filho, A. B. Desenvolvimento e estado nutricional da beterraba em função da omissão de nutrientes. Horticultura Brasileira, v.26, p.292-295, 2008. http://dx.doi.org/10.1590/S010205362008000200033

Assunção, N. S.; Clemente, J. M.; Aquino, L. A. de; Dezordi, L. R.; Santos, L. P. D. dos. Produtividade e eficiência de recuperação pela cenoura de nitrogênio, fósforo e potássio. Revista Caatinga, v.29, p.858-865, 2016. http://dx.doi.org/10.1590/198321252016v29n410rc

Avalhães, C. C.; Prado, R. de M.; Gondim, A. R. de O.; Alves, A. U.; Correia, M. A. R. Rendimento e crescimento da beterraba em função da adubação com fósforo. Scientia Agrária, v.10, p.75-80, 2009. https://doi.org/10.5380/rsa.v10i1.13173

Cavalcanti, F. J. de A. Recomendações de adubação para o Estado de Pernambuco: Segunda aproximação. 3.ed. Recife: Instituto Agronômico de Pernambuco, 2008. 212p.

Coutinho, P. W. R. Desempenho de cultivares, produtividade e qualidade de beterraba em sistemas de cultivo. Marechal Cândido Rondon: UEOPR, 2016. 62p. Dissertação Mestrado

Fageria, N. K.; Kluthcouski, J. Metodologia para avaliação de cultivares de arroz e feijão para condições adversas de solo. Goiânia: Embrapa Arroz e Feijão, 1980. 22p. Circular Técnica, 8
Fernandes, A. M.; Soratto, R. P. Response of potato cultivars to phosphate fertilization in tropical soils with diferente phosphorus availabilities. Potato Research, v.59, p.259-278, 2016. https://doi. org/10.1007/s11540-016-9330-Z

Fernandes, A. M.; Soratto, R. P.; Moreno, L. de A.; Evangelista, R. M. Qualidade de tubérculos frescos de cultivares de batata em função da nutrição fosfatada. Bragantia, v.74, p.102-109, 2015. http://dx.doi.org/10.1590/1678-4499.0330

Ferreira, D. F. Sisvar: A computer statistical analysis system. Ciência e Agrotecnologia, v.35, p.1039-1042. 2011. https://doi. org/10.1590/ S1413-70542011000600001

Harrill, R. Using a refractometer to test the quality of fruits and vegetables. 1998. Available on: <http://www.nutritionsecurity. org/PDF/Brix.pdf $>$. Accessed on: Abr. 2019.

Horta, A. C. S.; Santos, H. S.; Scapim, C. A.; Callegari, O. Relação entre produção de beterraba, Beta vulgaris var. conditiva, e diferentes métodos de plantio. Acta Scientiarum. Agronomy, v.23, p.11231129, 2001. http://dx.doi.org/10.4025/actasciagron.v23i0.2607

Luz, J. M. Q.; Queiroz, A. A.; Borges, M.; Oliveira, R. C.; Leite, S. S.; Cardoso, R. R. Influência da adubação fosfatada no teor foliar de fósforo e na produtividade de tubérculos de batata, cv. Ágata. Semina: Ciências Agrárias, v.34, p.649-656, 2013. http://dx.doi. org/10.5433/1679-0359.2013v34n2p649

Marques, L. F.; Medeiros, D. C. de; Coutinho, O. de L.; Marques, L. F.; Medeiros, C. de B.; Vale, L. S. do. Produção e qualidade da beterraba em função da adubação com esterco bovino. Revista Brasileira de Agroecologia, v.5, p.24-31, 2010.

Novais, R. F.; Smyth, T. J.; Nunes, F. N. Fósforo. In: Novais, R. F.; Alvarez V., V. H.; Barros, N. F.; Fontes, R. L. F.; Cantarutti, R. B.; Neves, J. C. L. (eds.). Fertilidade do solo. Viçosa: SBCS, 2007. Cap.8, p.276-374.

Nunes, J. A. S.; Silva, E. M. B.; Moreira, J. C. F. Produção de rabanete submetido à adubação fosfatada. Cerrado Agrociências, v.5, p.33-43, 2014.

Oliveira, R. J. P.; Gatiboni, L. C.; Valicheski, R. R.; Miquelluti, D. J.; Brunetto, G. Calibração da adubação fosfatada e potássica para beterraba na região do Vale do Itajaí. Horticultura Brasileira, v.34, p.210-215, 2016. http://dx.doi.org/10.1590/S0102-053620160000200010

Puiatti, M.; Finger, F. L. Cultura da beterraba. In: Fontes, P. C. R. (ed.). Olericultura: Teoria e prática. Viçosa: Editora UFV, 2005. Cap.22, p.345-354.

Sanches, J.; Cia, P.; Dias-Tagliacozzo, G. M.; Tivelli, S. W.; Purqueiro, L. F. V. Estudo comparativo de oito cultivares de beterraba mantidas sob condição ambiente. Horticultura Brasileira, v.26, p.S43-S47, 2008.

Sediyama, M. A. N.; Santos, M. R.; Vidigal, S. M.; Salgado, L. T. Produtividade e exportação de nutrientes em beterraba cultivada com cobertura morta e adubação orgânica. Revista Brasileira de Engenharia Agrícola e Ambiental, v.15, p.883-889, 2011. http:// dx.doi.org/10.1590/S1415-43662011000900002

Trani, P. E.; Tivelli, S. W.; Factor, L.; Breda Junior, J. M. Calagem e adubação da beterraba. Campinas: Instituto Agronômico de Campinas, 2013. 5p.

Wang, X.; Shen, J.; Liao, H. Acquisition or utilization, which is more critical for enhancing phosphorus efficiency in modern crops? Plant Science, v.179, p.302-306, 2010. https://doi.org/10.1016/j. plantsci.2010.06.007 